\title{
Evaluation of Quality of Service Provided by the Vocational Training Department
}

\author{
ALI Abdulhasan Dile ${ }^{1}$, ADIL Hamza Jasim², HAMEED Madhloom Kadhim³ \\ ${ }^{I}$ Department of Business Administration, Baghdad College of Economic Sciences University, Bghdad, (IRAQ) \\ ${ }^{2}$ Department of Finance and Banking, Baghdad College of Economic Sciences University, Bghdad, (IRAQ) \\ ${ }^{3}$ Department of Business Administration, Baghdad College of Economic Sciences University, Bghdad, (IRAQ)
}

\begin{abstract}
The subject of quality is one of the topics that penetrated the business world, because it constituted a big difference in the nature of the work of the organizations in all its specialties.

Therefore, this topic has attracted the attention of researchers and academics and they have been expanding in all areas of quality through which many organizations achieved competitive advantage in the market. Quality researchers are the quality of services that have become a necessity of the work of any organization because it reflects the permanence and survival of the product produced after the arrival to the customer and therefore the survival of the organization in the market and vitality and non-decay, On the contrary, the quality of services spread to smell Governmental organizations that are more demanding than others to provide the quality of services. This rapid development in our current world and the great openness and globalization posed a great threat to organizations, especially government organizations, which required the need for continuous evaluation and evaluation of the quality of services provided by The Vocational Training Department at the Ministry of Labor and Social Affairs helps them to cope with the current environment and the difficulties it faces and to identify the most important obstacles that it faces and work to remove them. On this basis, Introduction of a sample of (54) people from the departments of the Vocational Training Department through the questionnaire used as a tool for collecting information.

Numerous statistical methods were used to analyze the answers of the respondents through the statistical packages program to reach the required results. The researcher concluded, the need to find ways to raise the quality level by shortening the time and make the most of the services provided by the Internet.
\end{abstract}

Keywords: quality of service, vocational training

\section{JEL: L15}

UDK: 005.336.3:005.912

005.963.1

\section{Introduction}

Rapid developments in the organization environment and diversity in customer expectations have posed new challenges to the customer service function and the ability to recognize the requirements of the next generation of customers. Today, these requirements have grown and diversified considerably, so organizations have begun to study and understand the changes in customer needs and desires, adapt to them, share the customer, identify their vision and benefit from the suggestions they offer. Therefore, the service sector has grown significantly recently, His high strategic position in the international economic competition as a result of technological 
developments and information, where many of the economies of countries from the economy of manufacturing to the service economy, and this is due to the movement of the information age, which arose as a result of computer invention (Such as service organizations, education, finance, tourism, medical, transportation, etc.) has occupied a large position in the economies of the developed countries. They represent three quarters of the GDP in the United States and nearly $80 \%$ of the world's employment. Within the service organizations, the quality of services imposed the subject of evaluating the quality of service in administrative thought, for its importance to the organizations, which necessitated the organization to work to assess the quality of its services to be able to identify the vulnerabilities that pose a threat to them and to address them, Each ensures the continuation of its work successfully and excellence.

\section{Research Problem}

The administrative organizations in our time face a continuous momentum of environmental challenges and competitive conflicts resulting from the rapid changes in the working conditions and the development in the needs and desires of the beneficiaries and their transformation from one organization to the other in search of the best and most appropriate and quality. In addition, the working environment of organizations in Iraq is characterized by change and complexity, As the degree of uncertainty is very high in the political situation, economic and social, which has been suffering from instability for years to the present time, this situation reflected negatively on all sectors, especially the service sector. The Ministry of

Labor and Social Affairs is one of the service organizations working in this environment.

It is possible to summarize the problem of the study through the following questions:

1. What are the criteria on which the customer depends on his assessment of the quality of service provided by the Vocational Training Department?

2. Does the senior management of the Vocational Training Department recognize the concept and importance of quality of service?

3. What is the level of quality of service provided by the Vocational Training Service?

4. Does the management of the Vocational Training Service employ quality of service standards to obtain the highest quality of service?

5. Does the vocational training department achieve its objectives by developing the quality of its services provided, which is to meet the needs of the customer and society, which will positively affect the development and advancement of the industrial sector?

\section{Research Objectives}

Based on the research problem, the following objectives can be identified:

1. Identify the reality of the services provided by the Vocational Training Department.

2. Highlight the quality of service and its dimensions to the importance of how to perform the activities of the Vocational Training Service and ensure the survival and achieve the highest levels of customer satisfaction.

3. Evaluate the level of quality of service provided to the customer by the vocational training department and make recommendations to avoid deficiencies and remedy the imbalance.

4. Measuring the extent of the commitment of the Vocational Training Service to the dimensions of quality of service to achieve customer satisfaction.

5. To identify the necessary improvements required in the services provided and the impact on the selection of customers to service so that the Vocational Training Service to meet the current and future challenges. 


\section{The Importance of Research}

The importance of the research stems from the fact that it deals with an important and vital subject in one of the important state institutions (the Vocational Training Department in the Ministry of Labor and Social Affairs) which has a direct impact on the industrial sector which has never dealt with such topics before the researcher's knowledge. With the following points:

1. To direct the attention of organizations to work and focus on the dimensions of quality of service and its importance in order to achieve the optimal investment and use to compete in the business world by providing distinguished services to obtain qualified professional cadres in various disciplines contribute to the advancement of the country.

2. Focus on the role played by the quality of services in the development of the industrial sector as a vital sector and whatever needs to raise the level of progress and development of knowledge.

3. The nature of the work of the Vocational Training Service and the privacy of its customers requires management to be more careful and cautious in order to upgrade and excellence in the provision of services.

\section{Research Methodology}

In order to adopt a systematic approach to explore the contents of the research problem, and explore the gap in its cognitive and practical dimensions, and analyze and interpret it according to the foundations of scientific methodology, which is reflected on the objectives of the research, and the result of the diversity and multiple methods of measuring the subject of research, was based on the approach descriptive analytical approach Analytic Descriptive, Adopts the knowledge portal in the survey of the phenomenon formed by the problem of research, and it is the method that is characterized by a detailed description of the exact data and information obtained in order to draw conclusions. In order to reach conclusions and make recommendations thereon, $\mathrm{N}$ managers in vocational training department was a means of data collection is (questionnaire) for the views of the sample form.

\section{Research Limits}

1. Human Borders: A sample of 60 persons was selected by the departments of the Vocational Training Department as a sample for research.

2. Time Limits: The duration of the preparation of the research in the Department of Vocational Training, which began diagnosis of the problem of research, and the collection of scientific sources, and then write the theoretical side, and prepare the questionnaire, and distribution of the questionnaire and return, and interview managers and discuss their views and proposals on the research and objectives and variables and then prepare The practical side of the research is to analyze the results obtained and make appropriate recommendations. The period ranged from 1/11/2018 to 1/5/2019.

\section{Sources of Data Collection}

The study was based on a number of means by which data and information were collected on the study sample and analyzed according to the following:

A) Theoretical side: The theoretical aspect was covered by the use of books, literature, periodicals and Arab and foreign researches related to the subject as well as the use of the Internet. 
B) The practical side: The data on the practical side were collected through the questionnaire form as a main tool for collecting data from the study sample. It consisted of (7) dimensions that measure the quality of the services according to the nature of the work of the vocational training department divided into a number of questions. The Likert scale of the five-dimensional options, which is one of the most widely used methods in the administrative and social sciences, and the gradient is perfectly agreed (and offset by weight 5 ) is not fully agreed (and offset weight 1 ).

The questionnaire has been developed and adapted to the experts and arbitrators with scientific competencies in the subject of the research, the variables and the corresponding statements in the questionnaire.

\section{Tests for the Questionnaire Form}

1. Reliability of the questionnaire:

A) The test of the apparent truthfulness of the questionnaire: After the design of the questionnaire and the formulation of its expressions, it was presented to a group of experts and professors as arbitrators to identify their views in the question areas and the questions that fall under it and the consistency of each axis of the questionnaire with the main objective of the research.

B) The validity of the content test: The extent of clarity of each term of the terms of the scale in terms of concept and formulation and logical design, and through the use of the equation Cronbach's alpha.

2. The purpose of the statement of consistency of the questionnaire: is to ensure that the scale used to give the same results to be reapplied after a period of time on the same persons again. There are two methods used to calculate the stability coefficient:

The first method is to retest the test again, and this method is expensive and uneconomical.

The second method is called Half Split, which is to find the coefficient of correlation between the scores of the individual questions in the questionnaire and the scores of the marital questions. The correlation coefficient is corrected by the spearman Brown equation.

This is an indication that the measures used are of high stability and can be adopted at different times for the individuals themselves, The same results.

\section{Means of Analysis and Statistical Processing}

Some statistical measures were used for the nature of the data and the results are calculated, extracted and processed using the SPSS program to achieve the research objectives and statistical tests used:

1. Percentage: Used to give an idea of respondents' responses and to give an indication of their agreement or not.

2. mean mean (Mean) to determine the level of variables and trends and answers of the sample within the scale of the answer.

3. Standard Deviation: Shows the extent to which the answers are scattered around their computational circles.

4. Cronbach's alpha: Used to measure the accuracy of the questionnaire.

5. Relative importance (RelativeImportance): The importance of dimension or question for the variable.

\section{The Second Topic}

Quality of Service 
There were many approaches that addressed the concept of quality and this made it difficult to develop a unified definition of it. The ISO defines quality as the total characteristics of an entity (activity, product process, organization, system, individual or combination thereof) that reflects its ability to satisfy explicit and implicit needs (men and bolodans, 2). Quality is of strategic importance to various organizations, whether industrial or service, after it became clear that it represents the main factor in its success, especially as it is one of the most competitive priorities because of the increasing competition between local and international organizations. Organizations in The impact of the last century on the quantity of outputs because of the impact on the profitability of organizations and market share, which led to the situation of the Great Depression in the decade of the same century, which led the decision-makers in those organizations to review their goals and their presence, they had to To give great importance and high emphasis on the quality of outputs, whether those outputs material goods or services to suit the tastes of the public without neglecting the quantity.

The increasing service organizations and diversity in the quality of these services and the growing competition between them have paid attention to the quality of their service and excellence in serving their customers [1].

Quality of service is characterized by the difficulty of the concept to define its definition and achievement, but it is easy to identify when it is lost (Dupont, 2001). Customers are looking for quality service guides and draw conclusions about the quality of the place, equipment, tools, price, and communications they can see [2].

The concept of quality of service should be used to explain the nature of the service and to explain its concept, which differed from the views of the writers and researchers in defining one concept. There were many different concepts that dealt with this aspect due to the existence of services that are fully or partially connected with the material goods) while other services represent parts complementary to the marketing of goods sold such as maintenance).

And that there are types of services provided to the beneficiary without requiring a link to the goods such as health services and insurance [3].

Pena [4] refers to a service tariff as an activity or utility provided by one party to another and without the result of ownership of something, the provision of the service may or may not be associated with a physical product.

The researchers [5] defined them as intangible activities aimed at satisfying the desires of customers that are not necessarily related to the sale of another good or service. [6] showed that service is a description of customer requirements, how to satisfy them, understand their needs, and how to understand the organization's competitive priorities.

The concept of quality of service can be explained by what the researchers reported in their studies.

Hassoun [7] defines the ability of the organization to meet the needs and desires of the beneficiary to satisfy his needs and desires and exceed his expectations in keeping with the continuous developments and environmental changes to achieve his satisfaction and happiness.

Al-Darakka and Al-Shibli [8] point out that this is the quality that includes the procedural dimension of the specific systems and procedures for providing the service. The personal aspect of the service is the manner in which the employees are optimistic (their attitudes, behaviors and verbal practices) with the beneficiary.

The term "quality" means two concepts: the first relates to the service or the product itself, and the second relates to the relationship between the customer and the product or service.

Based on this connection, the concept considers quality in terms of the extent of conformity of the service or product to the specifications specified for it, Which indicates that the locations of the error can be easily identified and repaired before the customer is given, while the second indicates that the quality is the suitability of the service or product for the purpose for which it was produced. There is a separation between the two points of view between the service 
provider and the beneficiary. In the view of the service provider, it corresponds to the predetermined criteria for the service. From the point of view of the beneficiary, it refers to the compatibility of this service with its use and use [9].

\section{The Importance of Quality of Service}

Quality of service is of great importance to organizations aiming at achieving stability and success in the markets. In the area of commodity products, planning can be used in production and classification of products waiting for customers, but in the field of services, customers and employees work together to achieve and deliver the service at the highest level. And customers together (Jubouri, 2013).

Pooretal (2013: 35) points out that there are a number of reasons that oblige organizations to pay attention to the quality of services provided to customers to ensure their success in the market and its growth is as follows:

1. Increase customer expectations: The high expectations of customers for the past due to several factors, including increased awareness of customers and knowledge and advertising and the intensity of competition, which makes it imperative for organizations to pay attention to the quality of services provided.

2. Competitive activity: The constant change in the way the services are provided by competitors leads to changes in the markets, which forces the organizations to take steps to improve the quality of their services, especially in the markets that seek to enter them.

3. Environmental factors surrounding the organization: Laws and political, economic, social and cultural changes that represent the organization's working environment force the interest and constant search for ways of adapting to these factors by improving the quality of the services it provides to its customers.

4. The internal factors of the organization: By strengthening the activity of the organizations, which is to make continuous adjustments to the internal systems and the way to accomplish the tasks and duties commensurate with the diversity and change the needs and desires of customers.

5. Benefits arising from quality of service: Organizations benefit from the quality of services they provide, such as the organization's access to advanced market positions, high market share by comparison to competitors, and other factors that encourage organizations to seek quality services.

\section{The Dimensions of Quality of Service}

Quality of services is produced from a complex network of multiple dimensions. Over the years, researchers have worked to identify the most significant components of the quality of services on which customers base their expectations and perceptions and therefore their judgment on quality of service. However, [10]:

1. Access to the place of service: It is important to focus attention on access to places of service, whether physical facilities or public inquiry offices that make dialogue as easy and simple as possible.

2. Communication level: The organization's management must use the appropriate language that the customer understands easily. It is therefore important to simplify communication with the public using a simplified and understandable language.

3. Clarity in administrative systems: The diversity of administrative functions can make it difficult to understand how the management works, so strategies must be developed that can help to understand the work system by making such work simple to ensure customer satisfaction. It is important and certain that the customer knows the person who is solving their problems. In other words, find out who the customer should contact to get help or complain. 
4. Flexibility and responsiveness: Customers demand that the organization meet their real and specific needs. It is important that the focus is on how to answer and listen to their problems, to take care of their opinions and suggestions and to provide a degree of flexibility in the decision-making process that helps to adapt to environmental changes as quickly.

5. Participate in the design of the process of service delivery: Customers become more receptive if they participate in the design of the provision of service, as they have a significant impact in achieving customer satisfaction.

6. Efficiency of service providers: The technical capacity of the human resources of management is key to the provision of quality services.

7. Ability of employees to understand customers: The behavior of employees who represent the first line in the process of communication with customers is very important because they are providing services directly. Moreover, the friendly way of dealing with customers is a key element determines the quality of services.

8. Credibility: Credibility in service delivery is a set of principles such as equal treatment, fairness, or professionalism in the delivery of services, which is reflected in the degree of trust reflected by employees and management in the mindset of customers.

9. Reliability and responsibility in service delivery: Reliability is an attempt to gain customer confidence in a way that helps to create a better perception of the quality of public services, by providing services with consistency, accuracy and avoidance of arbitrariness. While attention to the concept of responsibility is of great interest by customers, which is one of the most important dimensions of quality of service in organizations.

10. Concrete aspects and availability of security: The customer must feel safe from various risks while receiving service. The adaptation of the work environment and the management structure plays an important role in the customer's judgment of the quality of service. It is important to take care of concrete aspects such as furniture, materials, etc. which reflect the image of quality in the customer's eyes.

(Hassoun [7] reveals that these dimensions have been reduced to an extended set of dimensions that can be applied in any service organization called the Servqual model, which is the same dimensions as [11]:

1. Reliability: Ability to perform the promised service reliably and accurately.

2. courteous (emotional adjustment): The service provider to be a great deal of respect and take into account the feelings of customers and deal with them while communicating with them.

3. Sympathy: Individual care provided by the organization to customers, including the ability to communicate and understand the customer.

4. Response: the ability to react quickly to meet customers' demands and provide services to them.

5. Intangible: It is the physical facilities, equipment and tools, and personnel employed and used when providing the service.

She adds [2] to the dimensions that have been mentioned:

1. Customer understanding: It means making efforts to understand customer needs.

2. Communication: The ability of the service provider to prepare well for the customer service and address them in the language they understand.

3. Safety: The extent to which the service is free of hazards.

4. Competence: The service provider has the skills and knowledge required to perform the service. 


\section{Application Side}

The questionnaire was used as a main tool for collecting data on the sample of the study.

Sixty questionnaires were distributed on the sample and 57 forms were retrieved and 3 forms were excluded for incomplete answers. The remaining 54 forms included 30 questions related to seven dimensions of service quality. Likert Al-Khamasi and Kalati:

- The paragraphs that have achieved arithmetical averages greater than 4 reflect an excellent and high quality of the content of that paragraph

- Paragraphs that have achieved arithmetic averages ranging from 3 to 4 reflect a good reality for the content of that paragraph.

- Paragraphs that achieved arithmetical averages ranging from 2 to 3 reflect a low reality of the content of that paragraph.

- The paragraphs that achieved a mean of less than 2 mean the agreement of the sample of the research on the very low reality of the content of that paragraph.

The questionnaire included thirty questions distributed on the dimensions of quality of service as follows:

1. After the Almncioa questions 1-4

2. Reliability questions 5-9

3. Responding questions 10-13

4. Sympathy Questions 14-18

5. $\quad$ Safety Questions 19-22

6. Contact questions 23-26

7. Customer understanding Questions 27-30

Stability: The Vaccronbach scale was used to measure the internal consistency of $(95.8 \%)$, which indicates a high level of internal consistency, noting that the value of laboratories accepted in scientific research is $(60 \%)$. The results are presented by each dimension of quality of service provided by the Vocational Training Service.

Results of a variable analysis after the concrete, according to the answers of the sample.

Table 1. The computational environment, standard deviations, and coefficient of difference, the relative importance of variable terms after the concrete

\begin{tabular}{|c|l|c|c|c|}
\hline NO & \multicolumn{1}{|c|}{ Paragraphs } & $\begin{array}{c}\text { Relative } \\
\text { importance }\end{array}$ & $\begin{array}{c}\text { standard } \\
\text { deviation }\end{array}$ & $\begin{array}{c}\text { Arithmetic } \\
\text { mean }\end{array}$ \\
\cline { 3 - 5 } 1 & $\begin{array}{l}\text { The rules and instructions are written simply and } \\
\text { conceptually }\end{array}$ & $26 \%$ & 1.21 & 3.19 \\
\hline 2 & $\begin{array}{l}\text { There are air conditioned, clean and comfortable } \\
\text { waiting rooms }\end{array}$ & $22 \%$ & 1.25 & 2.70 \\
\hline 3 & The staff look neat and good & $29 \%$ & 0.74 & 3.57 \\
\hline 4 & $\begin{array}{l}\text { The department uses modern equipments and } \\
\text { equipment in carrying out its work }\end{array}$ & $23 \%$ & 1.00 & 2.78 \\
\hline
\end{tabular}

The data of the results of Table Table (1) indicate the following:

(1) "The rules and instructions are written simply and conceptually" (3.19), which is higher than the mean mean of (3) and is confirmed by the standard deviation of (1.21) and the importance level of (26\%). This indicates a good and positive level for the simplicity of the rules and instructions and to present them in a clear and understandable manner.

B - The mathematical mean of paragraph (2) "There are 2.50 waiting rooms in the vocational training department, which is less than the satisfactory mean of (3), with a standard deviation of (1.25) and with an importance level of $22 \%$ To the lack of waiting rooms air conditioned, clean and comfortable to the required level." 
C - The arithmetical mean of paragraph (3) shows the workers to be "elegant and good" (3.57), which is higher than the mean means of (3) and is confirmed by the standard deviation of (0.74) and the importance level of (29\%). High elegance and arrangement.

D - The mathematical mean of paragraph (4) "The Vocational Training Department uses modern equipment and equipment in the completion of its work" amounted to (2.70), which is less than the satisfactory mean of (3) and a standard deviation of (1) and a level of importance (23\%), To not use the circuit equipment and modern equipment in the completion of its work.

Presenting the results of a variable analysis after reliability according to the answers of the research sample

Table 2. The computational environment, standard deviations, the difference factor, and the relative importance of variable terms after dependence

\begin{tabular}{|c|l|c|c|c|}
\hline NO & \multicolumn{1}{|c|}{ Paragraphs } & $\begin{array}{c}\text { Relative } \\
\text { importance }\end{array}$ & $\begin{array}{c}\text { standard } \\
\text { deviation }\end{array}$ & $\begin{array}{c}\text { Arithmetic } \\
\text { mean }\end{array}$ \\
\cline { 2 - 5 } 5 & $\begin{array}{l}\text { Time is strictly taken into account when executing } \\
\text { customer orders }\end{array}$ & $16 \%$ & 0.88 & 2.28 \\
\hline 6 & Customer rights are reserved by law & $20 \%$ & 1.23 & 2.80 \\
\hline 7 & Staff are very professional and skilled & $18 \%$ & 1.00 & 2.48 \\
\hline 8 & $\begin{array}{l}\text { The department is committed to completing transactions } \\
\text { in a short time } \\
\text { Do you feel that there is a continuous improvement in } \\
\text { the service provided in terms of simplification of } \\
\text { procedures and speed of delivery }\end{array}$ & $25 \%$ & 0.90 & 3.56 \\
\hline
\end{tabular}

The data in Table (2) indicate the following:

(2) The mean of paragraph (5) "The time is accurate when executing the customers' requests" for the reliability dimension (2.28), which is less than the satisfactory mean of (3) and the standard deviation of (0.88) and the importance level (16\%). Implementing customers' requests and not taking the time into account.

B - The arithmetic means of paragraph (6) "Customer rights reserved under the law" for the reliability dimension of (2.80), which is less than the satisfactory mean of (3) and a standard deviation of (1.23) and the level of importance (20\%). Somehow, they may be unsold by law.

$\mathrm{C}$ - The arithmetical mean of paragraph (7) "staff provide services professionally and highly skilled" for the reliability dimension of (3.04), which is higher than the satisfactory mean of (3) and is confirmed by the standard deviation of $(0.90)$ and the level of significance $(25 \%)$. And high skills of staff in providing their services to customers.

D - The computational mean of paragraph (8) "The department is committed to complete the transactions in a short wait time" for the reliability dimension of (2.48), which is less than the satisfactory mean of (3) and with a standard deviation of (1) and the importance level (18\%). Waiting for completion of transactions.

E - The arithmetic mean of paragraph (9) "Do you feel that there is continuous improvement of the service provided in terms of simplification of procedures and speed of delivery" of the reliability dimension of (3.56), which is higher than the satisfactory mean of (3) and confirmed by the standard deviation of (0.43) $25 \%$ This indicates a continuous improvement in service provided.

3 - Presenting the results of a variable analysis after the response according to the answers of the research sample.

Table (3) shows the computational environment, standard deviations and the relative importance of variable expressions after response. 
Table 3. Calculations, standard deviations and relative importance of variable after response

\begin{tabular}{|l|l|l|l|l|}
\hline NO & \multicolumn{1}{|c|}{$\begin{array}{c}\text { Paragraphs } \\
10\end{array}$} & $\begin{array}{l}\text { Relative } \\
\text { importance }\end{array}$ & $\begin{array}{l}\text { standard } \\
\text { deviation } \\
\text { from customers }\end{array}$ & $\begin{array}{l}\text { Arithmetic } \\
\text { mean }\end{array}$ \\
\cline { 3 - 5 } 11 & $\begin{array}{l}\text { Employees respond quickly to customer demand } \\
\text { despite work pressures }\end{array}$ & $25 \%$ & 0.96 & 2.89 \\
\hline 12 & $\begin{array}{l}\text { The department attaches great importance to } \\
\text { customer proposals }\end{array}$ & $29 \%$ & 1.00 & 2.72 \\
\hline 13 & Quick response to customer complaints & $20 \%$ & 1.21 & 3.22 \\
\hline
\end{tabular}

Table 3 data refer to the following:

A - The mean of paragraph (10) "The department welcomes the inquiries and inquiries of customers" after the response was (2.89), which is slightly lower than the satisfactory mean of (3) and a standard deviation of (0.96) and the importance level (26\%), The employees of the department welcome inquiries and inquiries from customers not to the required level.

B - The arithmetic means of paragraph (11) "Employees respond rapidly to customer demand despite work pressures" after the response was 2.72 , which is slightly below the satisfactory mean of (3) and with a standard deviation of 1 and $25 \%$ To respond to employees to ask customers is not fast.

C - The arithmetic means of paragraph (12) "The department pays great attention to customer proposals" after the response was (3.22), which is higher than the satisfactory mean of (3) and a standard deviation of (1.21) and the importance level (29\%). Customers received great attention from the department.

(13), the speed of responding to customers' complaints, after the response, was 2.26, which is lower than the satisfactory mean of (3), with a standard deviation of (0.87) and the importance level $(20 \%)$. On customer complaints is weak.

Display the results of a variable analysis after empathy according to the answers of the research sample.

Table (4) shows the computation, standard deviations, and relative importance of variable expressions after empathy

Table 4. Computational and standard deviations and the relative importance of the variable after empathy

\begin{tabular}{|c|c|c|c|c|}
\hline NO & Paragraphs & $\begin{array}{l}\text { Relative } \\
\text { importance }\end{array}$ & $\begin{array}{l}\text { standard } \\
\text { deviation }\end{array}$ & $\begin{array}{l}\text { Arithmetic } \\
\text { mean }\end{array}$ \\
\hline 14 & $\begin{array}{l}\text { The department staff is characterized by a friendly } \\
\text { and friendly spirit in dealing with the customer }\end{array}$ & $27 \%$ & 0.76 & 3.63 \\
\hline 15 & $\begin{array}{l}\text { Employees do not complain when customers ask too } \\
\text { many or troublesome questions }\end{array}$ & $23 \%$ & 0.80 & 3.07 \\
\hline 16 & $\begin{array}{l}\text { The workers who answer the phone are always } \\
\text { attentive to the speaker's feelings }\end{array}$ & $15 \%$ & 1.00 & 2.06 \\
\hline 17 & $\begin{array}{l}\text { Each customer receives personal attention from the } \\
\text { department staff }\end{array}$ & $14 \%$ & 0.73 & 1.91 \\
\hline 18 & $\begin{array}{l}\text { The workers deal with elegance, friendliness and } \\
\text { respect with the customer }\end{array}$ & $20 \%$ & 1.20 & 2.63 \\
\hline
\end{tabular}

The data in Table (4) indicate the following:

(15) "Employees do not complain when customers ask many or troublesome questions" to a variable after sympathy for the quality of service provided by the vocational training service. (3.63) and (3.07) respectively, higher than the mean mean of (3) and with a standard deviation of (0.76) and (0.80) respectively. The importance ratio was (27\%) and (23\%), Customers were higher than the other paragraphs of the distance of sympathy and these figures indicate that the workers in the circle are characterized by a high degree of excellent spirit of fun and friendship 
in the meeting They are with the customers do not seem any discomfort or complained to the large number of customer questions.

(B) When reviewing the computational environment, standard deviations and the relative importance of the remaining paragraphs on the dimension of empathy, 16 "the workers who respond to the phone are always attentive to the speaker's feelings" and " 17 each customer receives personal attention from the staff of the department" and (3), ranging between (1.934.63), with a standard deviation of (0.73-1.20) and a relative importance ranging between (14\%$20 \%$ ). Which indicates a low level of consideration for the feelings of the speakers of customers when answering the phone as well as low level of interest to the customer b Personal Subject to by the department staff with a low level of tact somewhat with respect to customer and this indicates the lack of agreement by a small percentage points of view sample from these paragraphs, compared with paragraphs Alokhrybad empathy.

4 - Display the results of a variable analysis after safety according to the answers of the research sample.

Table (5) shows the computational dynamics, standard deviations and the level of significance of variable expressions after safety.

Table 5. Calculations, standard deviations and the level of importance of the variable after safety

\begin{tabular}{|l|l|l|l|l|}
\hline NO & \multicolumn{1}{|c|}{ Paragraphs } & \multicolumn{1}{|c|}{$\begin{array}{l}\text { Relative } \\
\text { importance }\end{array}$} & $\begin{array}{l}\text { standard } \\
\text { deviation }\end{array}$ & $\begin{array}{l}\text { Arithmetic } \\
\text { mean }\end{array}$ \\
\cline { 3 - 5 } & $\begin{array}{l}\text { Safety and safety devices are available in the department } \\
\text { to ensure the safety of employees and customers when } \\
\text { they are present }\end{array}$ & $21 \%$ & 0.86 & 2.85 \\
\hline 20 & $\begin{array}{l}\text { The Department maintains confidentiality of customer } \\
\text { information }\end{array}$ & $24 \%$ & 1.22 & 3.30 \\
\hline 21 & $\begin{array}{l}\text { Employees shall enjoy personal safety in the } \\
\text { performance of their duties }\end{array}$ & $30 \%$ & 0.58 & 4.04 \\
\hline 22 & $\begin{array}{l}\text { Citizens feel safe and comfortable when they are in the } \\
\text { circle }\end{array}$ & $25 \%$ & 1.42 & 3.48 \\
\hline
\end{tabular}

Table 5 data refer to the following:

A) When reviewing the computational environment, standard deviations, and the relative importance of safety profiles, we found that all sub-variables were computationally higher than the mean mean of (3), ranging between (3.30-4.04) except paragraph (19) Safety and safety devices that ensure the safety of workers and customers when they are present, which was (2.85) less than the average satisfactory slightly, and in general, the answers indicate that there is satisfaction with the safety distance for the quality of services felt by the customer and the Department pays good attention to this dimension and significantly.

5 - Display the results of a variable analysis after contact according to the answers of the research sample

Table (6) shows the computational environment, standard deviations and relative importance of variable terms after contact. 
Table 6. Calculations, standard deviations and relative importance of variable after contact

\begin{tabular}{|c|c|c|c|c|}
\hline NO & Paragraphs & $\begin{array}{l}\text { Relative } \\
\text { importance }\end{array}$ & $\begin{array}{l}\text { standard } \\
\text { deviation }\end{array}$ & $\begin{array}{l}\text { Arithmetic } \\
\text { mean }\end{array}$ \\
\hline 23 & $\begin{array}{l}\text { Employees can use more than one language when } \\
\text { speaking with customers }\end{array}$ & $14 \%$ & 1.43 & 1.59 \\
\hline 24 & $\begin{array}{l}\text { The department uses modern means of communication } \\
\text { such as the Internet and others to exchange information } \\
\text { with customers }\end{array}$ & $31 \%$ & 1.14 & 3.63 \\
\hline 25 & $\begin{array}{l}\text { Customers receive the required response for all their } \\
\text { inquiries }\end{array}$ & $29 \%$ & 0.48 & 3.33 \\
\hline 26 & $\begin{array}{l}\text { The customer can access certain services through the use } \\
\text { of various means of communication }\end{array}$ & $27 \%$ & 1.34 & 3.09 \\
\hline
\end{tabular}

Table (6) indicates the following:

(24) "The department uses modern means of communication such as the Internet and others to exchange information with customers", 25 "customers receive the required response for all their inquiries" and (26) the customer can obtain some services through the use of (3.09-3.63), which is higher than the satisfactory mean of (3) and in harmony with the responses of the sample items confirmed by the standard deviation between (0.48-1.34) and the level of importance ranged from (27\%-31\%). This confirms the sample agreement on the importance of these paragraphs and their satisfaction.

B) When reviewing the computational and standard deviations of paragraph (23), "the staff can use more than one language when talking to clients" of the contact dimension, we found that the mean was less than the mean (3) and a rather high standard deviation (1.43) Due to the respondents' dissatisfaction and satisfaction with the use of more than one language when talking to customers. The sample did not receive the attention of the sample when the percentage of importance was low (14\%) and achieved the lowest value among the other paragraphs of this dimension. In general, there is a somewhat acceptable satisfaction by customers to the paragraphs of this dimension.

6 - Presenting the results of a variable analysis after the customer understands according to the answers of the research sample.

Table (7) shows the computational environment, standard deviations and the relative importance of variable expressions after customer understanding.

Table 7. Calculations, standard deviations and relative importance of variable after customer understanding

\begin{tabular}{|c|c|c|c|c|}
\hline NO & Paragraphs & $\begin{array}{l}\text { Relative } \\
\text { importance }\end{array}$ & $\begin{array}{l}\text { standard } \\
\text { deviation }\end{array}$ & $\begin{array}{l}\text { Arithmetic } \\
\text { mean }\end{array}$ \\
\hline 27 & $\begin{array}{l}\text { Employees can make changes to the } \\
\text { required services easily }\end{array}$ & $31 \%$ & 0.75 & 3.31 \\
\hline 28 & $\begin{array}{l}\text { The service is tailored to the customer's } \\
\text { position }\end{array}$ & $26 \%$ & 1.16 & 2.78 \\
\hline 29 & $\begin{array}{l}\text { Employees can meet the needs and } \\
\text { desires of each customer individually }\end{array}$ & $18 \%$ & 1.10 & 1.87 \\
\hline 30 & $\begin{array}{l}\text { Management is always the right of the } \\
\text { customer }\end{array}$ & $25 \%$ & 0.77 & 2.59 \\
\hline
\end{tabular}

The data in Table (7) indicate the following:

(A) The mathematical mean of paragraph (27) "Employees can make changes to the services required easily" for a variable after the customer's understanding of the quality of service provided by the vocational training service (3.31), which is higher than the satisfactory mean of (3) The sample was confirmed by the standard deviation (0.75), but the importance was the highest among the paragraphs after the customer's understanding (31\%), indicating the high ability of the employees to make changes to the services required easily. 
(B) When reviewing the computational environment, standard deviations and the relative importance of the remaining paragraphs of the expressions of customer understanding dimension (28) "the service is commensurate with the customer's position" and (29) "employees can meet the needs and desires of each client individually" and (30) We found that these paragraphs were less than the average mean (3), ranging between (1.87-2.78) and the percentage of importance ranged between (18\%-26\%), which means that the agreement

The views of the sample items are largely related to the suitability of the services provided to the customer with his position and the employees in the department can not meet the needs and wishes of the customer Different customer and that the customer is not always right, and this indicates a decrease in the level of customer satisfaction for these paragraphs in this dimension.

\section{Conclusions and Recommendations}

This study reached a number of conclusions, the most important of which are:

1. The statistical analysis of the responses of the research sample to the quality of service provided by the vocational training department showed a good level of service for some of the juniors and some of the others. This indicates that the actual level of service provided meets the needs and desires in some aspects and does not meet these needs and desires in others. Encourages the development of positive services provided and attention to aspects of services whose quality has decreased to achieve the highest levels of satisfaction.

2. The safety dimension ranked first in the evaluation of the members of the research sample to the actual level of service provided to them by the Vocational Training Department. This reflects the great interest that the Department attaches to providing security and safety by providing safety devices and maintaining the confidentiality of information. His presence in the organization.

The tangible dimension was ranked second in the evaluation of the members of the research sample for the actual level of service provided to them by the Vocational Training Department. Which reflects the attention of the Department to the convenience of customers by providing all amenities in a clear and tangible by the customer.

The contact dimension ranked third, followed by reliability, response and follow-up. The customer's understanding was ranked last in the evaluation of the members of the research sample for the actual level of service provided to them by the vocational training department.

Which reflects the low level of service in these aspects and the low level, which reflects the customer's dissatisfaction with those services provided. By the Vocational Training Service.

\section{Recommendations}

From the findings of this study, we can provide a set of recommendations that we believe may be appropriate to enhance the performance levels of the vocational training department and to develop its business and improve quality in it:

1. the need to accelerate the use of modern technologies in the completion of work and rely on the possibilities of the Internet.

2. The need for the Department to review the process of completing transactions, which reduces the time required to complete them.

3. The necessity of interest of the company to involve staff in development courses related to their tasks to increase their expertise and skills.

4. To attract and employ the best talent through the use of scientific methods in the process of selecting individuals to fill the vacancies in the selection of young and 
competent elements capable of development and the use of modern technologies and keep pace with the development of work at the global level.

5. Development of administrative and technical elements through the inclusion of these elements in intensive specialized courses within and outside the department periodically and continuously focused on providing employees with expertise, knowledge and communication skills. And allowed some of them to complete their higher studies in order to provide young cadres able to manage the Department in the future.

6. the need to devote efforts towards customer satisfaction and continuous and constant search for his needs and desires by increasing interest in ongoing and periodic field surveys about customers and identify the services they desire and respond to them and to view complaints and work to solve them radically.

7. The Vocational Training Department shall make more efforts to take care of qualified employees and gain satisfaction in order to ensure their continued work by improving the living conditions, material and moral, and informing them that they are important figures.

8. The importance of spreading the role of the culture of quality and spreading it among the employees to accomplish their tasks at a level that meets the expectations of customers.

9. The need for the Vocational Training Department to hold seminars and intensify them by hosting the old employees with distinguished experience and listening to their opinions and suggestions and understanding their needs, desires and expectations about the level of service performance and work to meet them.

\section{REFERENCES}

1. Hussein, Attizar Aziz (2010), "The Impact of Strategic Analysis on Quality of Service (A Survey of Directors' Opinions in a Sample of Iraqi Banks)", Master Thesis.

2. Shammari, A. Zahra Abdul-Mohammed, (2010), "Quality Management Levels in Service Organizations (Case Study in Private Nursing Hospital/Department of Medicine City)", Journal of the University of Babylon/Humanities.

3. Sumaidaie, Mahmoud Jassim, and Alalak, Bashir Abbas, "The Basics of Integrated and Integrated Marketing", Dar Al-Mihaj, 2002.

4. Kotler, P., "Marketing Management", 10 10 ed., Prentice-Hall, Inc, New Jersey, 2000.

5. Etzel, M.J., and Walker, B.J., Stanton, W.J., "Marketing”, 12 $12^{\text {th }}$ ed., Mc Graw-Hill, 2001.

6. Davis, M., and Heineke, J., "Managing Services", International McGraw-Hill Co., Inc., North America, 2003.

7. Hassoun, A. Rizan Abdulrahman (2015), "The Effect of Organization Quality in Improving the Organization's Quality” (“Analytical Head of Iraqi Airways”), Master Thesis, Faculty of Management and Economics, University of Mustansiriya.

8. Dararaka, A. Mamoun, Al-Shibli, Tareq, (2002), "Quality in Modern Organizations”, Dar Al-Safa Publishing, First Edition, Amman, Jordan.

9. Krajewski, L., and Ritzman, L., “Operations Management: Strategy \& Analysis”, Addison Wesley Publishing Company, New York, 2000.

10. Rodriguze, Pablo Gutierrez, Burguete, Jose Luis Vazquez, Edwards, Jonathan, "quality dimensions in the public sector: municipal services and citizen's perception”, Int REV Public Nonprofit Mark.DOI 10.1007/s12208-009-0030.

11. Nakhai, Behnam\& S. neves, (2009), "The challenges of six sigma in improving service quality", International Journal of quality \& Reliablity Management, Vol. 26 No. 7.

\section{Article history:}

- Received 30 August 2019

- Accepted 10 November 2019 